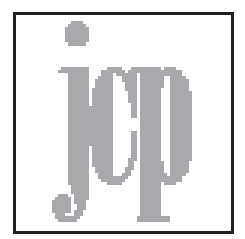

\title{
Reading, Writing, Living in an Era of Pandemic
}

\author{
Muneeza Shamsie \\ Independent Scholar/Literary Historian \\ mshamsie@gmail.com
}

I seem to live in a world suspended in time. I work on essays I need to deliver. I listen to online discussions and book launches. Sometimes I watch world-wide live-streamed ballets or dramas. I join yoga classes on Zoom. I make jam. My elder daughter, Saman, bakes sour dough bread. I count my blessings and that I have my family with me, both my husband, Saleem and two daughters, Saman and Kamila - the latter has come to Karachi for the winter, from London, where she lives. Now there is the global excitement of a new vaccine alongside the fears generated by new virus mutation in Britain. Where will it all lead? I am possessed by a strange sense of the surreal. I can hardly remember where I spent the New Year in Karachi a year ago. All those get-togethers with old friends, including those visiting from Islamabad, Lahore and the diaspora, seem a mere illusion, as do our bright ideas for travels plans to cooler climes in the summer, where I would attend literary conferences too. Nowadays, my outside world is my garden, mostly. I am grateful for that: it is filled with chirping birds and frequented by lively stray cats that we feed. We have lived here for forty years.

Sometimes in the mornings, as I pass Saman's room, I hear her talking. She is a primary school teacher. She is instructing her pupils online in clear precise tones. Her workplace is the antique colonial ladies desk with a foldable top and drawers that belonged to my late mother, Jahanara Habibullah (19152003). I wonder what my mother have thought of this "virtual reality" and our "virtual lives" - all of us, even my sister, Naushaba in distant Montreal, overtaken and closeted by a pandemic.

I then realise that my mother was well acquainted with virulent infections and epidemics. She grew up in Rampur and nearly died of typhoid at nineteen. The fever raged on for three months. She mentions this in her memoir Remem- 
brance of Days Past (2001) but not the detail she told me: she knew she was dying because she overheard her nurse weep at the imminent loss of someone so young, gentle and beautiful. Miraculously my mother survived, thanks to her uncle, a distinguished medical doctor. Three years earlier, her elder sister, had developed tuberculosis. The recommended sojourn in Dehra Dun, with its clear, healthy mountain air did not cure her. Their medical uncle suggested a sanatorium in Switzerland. My grandfather agreed. Fakhra aged seventeen was accompanied by sister Jahanara, aged sixteen, and their mother. They all discarded purdah. This caused such outrage that Fakhra's fiancé, and cousin, broke off their engagement. But there were few regrets. My aunt regained her health and a new life opened out for both sisters. My mother writes, "We lifted our eyes at the world in amazement when we came out of purdah" (Habibullah 53)

Almost a century later, with Covid-19 spreading rapidly, I wonder what the future holds. What changes will it bring about in individual lives, cultures and countries across the world? I think of how fortunate we are that so many infectious diseases are preventable or treatable now, even if they have yet to be eradicated. In my childhood, there were mandatory cholera and typhoid injections and smallpox vaccinations whenever I travelled I was sent to boarding school in England at nine and came home to Pakistan every alternative summer. Around 1960-61 smallpox broke out in England, apparently brought in by newly-arrived Pakistanis. I saw the words "Pakis Get Out" emblazoned on walls and the underground, everywhere, during a visit to London.

I vividly recall that global pandemic, the Asian flu, c. 1958, at my small, cloistered Victorian school in Sussex. We were told little about the disease, except that it was very infectious. That autumn, our dormitories were rapidly turned into sanatoriums. Everyone fell ill — except for six girls including Naushaba and me. I just remember being fedup with that great British enthusiasm for "fresh air" and exercise, even in wet freezing weather, as a preventative.

In distant Karachi, my father Isha'at Habibullah (1911 — 1991) had another theory: Naushaba and I did not catch the Asian flu because he had plied us throughout our summer holidays, with his new discovery: Ascorbon- those sweet, chewable 500mgVitamin C tablets. All these years later, with the outbreak of Covid-19, I find Vitamin C is a recommended precaution (as are fresh air and exercise). I think of my large individualistic father often, as I dole out similar tablets to my family - and discover they are much in demand in the local pharmacies.

In the 1950's the Asian flu claimed over a millions lives globally, but 
the Spanish flu of 1918 - 20 led to 50-100 million deaths, a greater number than World War I (1914 - 1918). The Spanish flu is the subject of Emma Donoghue's new novel The Pull of the Stars (2020), narrated by a nurse in a Dublin hospital. I will read it soon. By chance, Donoghue had just finished the book, when Covid-19 broke out. Her publishers speeded up its publication. Reviewers commented on its have uncanny resonances with Covid-19 times, including the loss of loved ones, the fear of infection, the pressures of lockdown and the empty schools, shops and cafés.

In pre-Partition India, the Spanish flu, arrived via Indian soldiers returning from Europe's World War I battlefields, spread like wildfire and killed 1718 million (Biswas). Mahatma Gandhi and infected associates in an ashram were among its survivors (Biswas). I turn to Ahmed Ali's novel Twilight in Delhi and his words:

Nature herself was rebellious and seemed angry with the people of the Hindustan. Hundreds and thousands of Indians had been killed in the war, acting as fodder to the German guns. But not content with this and, as it were, filled with anger against the inhumanity of man, Nature wanted to demonstrate her own callousness and might. Influenza broke out in epidemic form. (Ali 242)

Ali's novel suddenly assumes a new dimension for me. His comment on nature's revenge for mankind's brutalities foreshadows the discussions today on the ecological disasters which have caused the virus mutation that created Covid-19. Ali's harrowing portrait of Delhi overtaken by the Spanish flu describes mohallas filled with "heart rending cries and lamentation" (242). The plight of the poor, the overcrowded cemeteries and the antics of exploitative traders and thieves are all built in.

The city that Ali describes is now the historic Old Delhi, to which my maternal grandmother belonged. During my childhood visits from Pakistan to India, we would call on her brother who lived in the family home in Gali Qasim Jan. I vividly recall its narrow lanes lined with houses, their interior hidden from view until the arched gates opened to reveal spacious courtyards, flanked by verandahs with fluted arches.

In the enclosed world that I inhabit during Covid times, I find myself looking at the books that I read and write about, from a different perspective. My mother loved Urdu poetry and often she and her siblings would sit and analyse Ghalib's poetry in particular. I now learn that Ghalib lived through several epidemics including cholera and smallpox. There is something chilling in the discovery that an epidemic had claimed Ghalib's adopted son, Zainul Abedin Arif 
(my mother's forbear) though I knew he had died young. I revisit Ghalib: Life and Letters by Ralph Russell and Khurshidul Islam and notice how often Ghalib mentions the outbreak of nameless infections. He refers to Arif's failing health, the ru'af (severe nosebleed) he suffers from and that Arif's wife has been "suffering from fever and a persistent cough" for three months (105): in 1852, husband and wife die within months of each other. In 1854 an "outbreak of fever" (107) infects the neighbourhood. Arif's orphaned son Hussain Ali, adopted and much loved by Ghalib, almost dies too. The letters include the 1860 cholera epidemic which follow the traumas of the 1857 ghaddar. Later, Ghalib escaped the 1858 - 59 smallpox epidemic, in the last year of his life.

In this day and age of social media, the limited knowledge of Covid-19, has led to a proliferation of videos, messages and fake news of possible preventions and cures. Jamil Jan Kochai's 99 Nights in Logar (2019) is narrated by a 12year old Afghan-American visiting his family home in Logar, Afghanistan. At one point, a mysterious illness overtakes his extended family, living in a compound of interlinked courtyards and verandahs. The access to medical facilities and diagnosis is limited, beyond home-made herbal remedies. Everyone must quarantine. Kochai's combination of the real and surreal in this multi-layered novel, turns this incident into a symbolic microcosm of both the past and the present.

To me, one of the most unexpected aspects of the Covid-19 is how the political and public responses to this unknown virus, in diverse countries, have blurred the much-touted divide between the First and Third Worlds. Alas this is not the result of any achievement or advancement, but similarities in human behavior. Political leaders hold public gatherings and vie for power, with little concern for public welfare. Many people, rich or poor, literate or illiterate, insist that the dangers of Covid-19 are exaggerated, or an insidious 'foreign plot', or engineered by 'hidden hands.' In Karachi, my friend's servant says that on a recent visit to his family village, he was scorned for wearing a mask and people deliberately coughed in his face, as a joke. A highly educated American woman writes to my American colleague, that unlike him, she has no intention of listening to 'TV propaganda' or 'so-called doctors' on the dangers of the pandemic which, in her opinion is not about health, but 'control'.

In the confusion, uncertainty and different degrees of lockdown across the world, millions long for normality. But Covid-19 continues its unrelenting journey. In Pakistan the newspapers are filled with obituary notices, but the traditional announcement for funeral and soyem timing for people to gather, are replaced with the words 'Please say duas at home'. The recent loss of my friends 
from Covid-19 or from protracted illnesses, is a reminder of how important these rituals are as a farewell and as comfort through human contact. I try not to think of the terrors of Covid, including the suffering of those unable to see their loved ones during their last days. I can only be glad that many have recovered from this unpredictable illness - and that the vaccine will be available soon. Several people I know have volunteered for the vaccine trials at Karachi's major hospitals.

I turn to a newly published anthology The Stained-Glass Window: Stories from the Pandemic in Pakistan edited by Sana Munir and Taha Kehar. Mehvash Amin's introduction, a poem “Covid-19”, begins with:

The fabric of these days / is run through with death / / I do not want this/Sly droplet /

To insinuate itself/Into the cells that make me/Duping them into turning/Traitor

The collection consists of stories which speak so directly of complex experiences and emotions in this new uncertain world. Aamer Hussein recreates the experiences of a London-based Pakistani writer, where glimpses of natural life are interwoven with memories of friendship and loss. Attiya Dawood tells of family life disrupted by the demands of children during confinement; Taha Kehar describes a Zoom wedding disturbed by an uninvited guest; in another story, he juxtaposes the solitude of a young girl and her elderly delusional neighbour during lockdown. Sana Munir looks at the pandemic's pressures on a doctor and her hospital. Shahbano Alvi captures the fears of a family with ailing elders, when friends test Covid-positive. Awais Khan portrays the crisis of family man dismissed from his job.

All these stories and others in the collection capture very real dimensions of life today. I look forward to Singing in the Dark: A Global Anthology of Poetry under Lockdown edited by K. Satchidanandan and Nishi Chawla (2020) which includes over 100 international poets, including the Pakistan-born Waqas Khwaja.

As I write this, 2020 gives way to 2021; it seems incredible that a year ago, I frequented cinemas and restaurants, attended a heritage conference at Makli, a performance by Khalid Ahmad of King Lear in Urdu and literature festivals in Islamabad, Karachi and Lahore. By mid-March 2020, Covid had clearly arrived; I reluctantly abstained from attending the NAPA International Theatre Festival. I was glad indeed that both Kamila in London and Saman in Karachi, teaching at a university and a school respectively, had switched to working online, as had family and friends in different professions, everywhere. What this augurs for the future remains to be seen. Saleem is now retired. He used to run his own business and is very aware of the pandemic's adverse impact on the livelihood of so many, particularly countless workers being laid off work. We remain impressed at the 
way Karachi's wonderful philanthropic organisations swung into action to help the needy.

In March 2020, the Sindh Government imposed a strict lockdown. The local stores I used to frequent started excellent delivery services which I have used ever since. Once, when I ventured out, I was most impressed to see beggars at a traffic light wearing masks! In those days the traffic was limited and the road outside our house became so quiet, that it was ideal for our evening walks. We often passed friends or acquaintances living in the neighbourhood. Some were accompanied by their dogs, or children; one or two of the latter would pedal past, under parental eye. There was a great sense of camaraderie as we waved to each other and shouted greetings across the street. One day Saman and her friend Zehra walked down in the opposite direction towards the Seaview beach. This normally busy, crowded place, was now deserted and guarded by two policemen on horseback, but the two girls were permitted to take photographs. The images of that pristine grey sand in the distance and the sea merging with the sky reminded me of the coastline around Clifton beach and beyond, during my childhood: in those days the area where I live now, was but sand and rock.

In that distant time, my father was an executive in a multinational which he later headed. We lived in beautiful colonial buildings on Clifton Road, which have since been replaced by multi-storied structures, as has much of the Karachi's architectural heritage. I pick up Maniza Naqvi's memoir, A Guest in the House (2018), a fascinating account of how she rescued The Pioneer Book HouseKarachi's oldest bookshop--from being sold. The bookshop is among the surviving historical structures in that overcrowded commercial hub, M. A. Jinnah Road (Bundar Road in my childhood) leading towards the harbour. Naqvi's exploration of that architecture and the city's history conjures up the ambience of the area and its inhabitants and indeed the Karachi of the early post-Partition years. All this is interwoven with tales of supportive Karachi friends and colleagues and the city's literary and cultural life. Somehow remembering a historic past and linking it to the pre-pandemic present, assumes a particular significance in Covid times. It also poses that burning question: how will the bookshop and indeed the entire city cope with pandemic's fallout?

Meanwhile a new world has opened out for me online: conferences on Zoom, live-streamed literary festivals from the world over and above all, live streamed performances from London, since the theatre is central to my trips there. Now sitting at home, I see the Akram Khan Dance Company performance at Sadler's Wells of Until the Lions based on Karthika Nair's poetry retelling the 
Mahabharata. I listen to The Odyssey translated by Emily Wilson, read out by celebrated actors in the West End, which highlights the fact that this amazing text was intended for oral recitation — and yes I think of my Oxford-educated father who loved reading Homer in Greek. A link to SOAS festival takes me to a documentary on Anna Pavlova's influence Uday Shankar. These online events reach audiences far beyond the auditorium, which is likely bring about many changes. Of course, I was delighted to be invited to participate in the Lahore Literary Festival, the Islamabad Literature Festival and the World Festival of Poetry. We celebrated the New Year, with the online launch of Saman's new storybook for children Where the Rivers Meet, moderated by Mahvesh Murad; while Kamila, a novelist is part of a project inviting well-known women writers to reconstruct age-old fairy tales. To my delight, her Duckling (a version of The Ugly Duckling) has arrived in Karachi.

Meanwhile, Covid continues to rule our lives. At first, there was a conflict between the Sindh government and the federal government over the need for a lockdown. Gradually both adopted 'smart lockdowns' targeting areas with high infection rates. In May however, Pakistanis was devastated by PIA air crash near Karachi Airport with few survivors. The monsoon brought downpours throughout the country and, in Karachi, the worst in 100 years, leading to devastating floods and great suffering. But the fact that by July-August Pakistan had managed to bring down the spread of the virus, meant that many people forgot its dangers altogether. Today Covid-19 is on the rise in Pakistan again and despite attempts to control large gatherings, many seem oblivious of quarantine, or precautions; on New Year's Eve, we had music blaring from a nearby house all night. My family, friends and I, wear masks whenever we go out, we wash our hands, when we come in. We isolate and get ourselves tested, if we are unwell, or travel. On the rare occasions we meet, we prefer to sit outdoors and observe social distancing. This month, we saw the New Year in en famille-just Saleem, Saman, Kamila and I - and as we sat down to a dinner with a dish cooked by each one of us, I counted my blessings, once again. 


\section{Works Cited}

Ali, Ahmed.Twilight in Delhi. 1940. Oxford University Press (Karachi), 1984. Amin, Mehvash. "To Covid-19”. The Stained-GlassWindow: Stories from the Pandemic in Pakistan. Eds. Sana Munir and Taha Kehar. Karachi, 2020.

Biswas, Soutik. "Corona virus: What India can learn from the deadly 1918 flu" BBC News, 18 March 2020, https://www.bbc.com/news/worldasia-india-51904019

Habibullah, Jahanara. Remembrance of Days Past: Glimpses of a Princely State During the Raj. Trans. Tahira Naqvi. Karachi: Oxford University Press, 2001.

Kochai, Jami. Jan. 99 Nights in Logar. London: Bloomsbury, 2019.

Munir, Sana and Taha Kehar. eds The Stained-GlassWindow: Stories from the Pandemic in Pakistan. Karachi: Liberty Publishing, 2020.

Naqvi, Maniza. Guest in the House. Karachi, 2019.

Satchidanandan, K. and Nishi Chawla, eds Singing In The Dark : A Global Anthology of Poetry Under Lockdown. New Delhi: Penguin Random House, 2020.

Shamsie, Saman. Where the Rivers Meet. Karachi: Oxford University Press, 2020.

Shamsie, Kamila. Duckling. London: Vintage Children's Classics, 2020.

Russell, Ralph and Khurshidul Islam. Ghalib: Life and Letters. London:Allen and Unwin, 1969. 